\title{
1. Regulation of PPP and concessions in European Union law - different but equal?
}

\section{Piotr Bogdanowicz}

\section{INTRODUCTION}

European Union public procurement law is a bundle of different notions and concepts. First of all, it differentiates between 'public contracts', which are regulated by Directive 2014/24/EU1, 'contracts' regulated by Directive 2014/25/EU2 and 'concessions', regulated by - for the first time in the history of European Union public procurement law by a standalone instrument - Directive 2014/23/EU. ${ }^{3}$ All these arrangements must involve 'procurement'. ${ }^{4}$ A core notion behind public contracts, contracts and concessions is, however, that of a 'contract'. It is because public contracts,

1 Directive 2014/24/EU of the European Parliament and of the Council of 26 February 2014 on public procurement and repealing Directive 2004/18/EC, hereinafter the Classic Directive.

2 Directive 2014/25/EU of the European Parliament and of the Council of 26 February 2014 on procurement by entities operating in the water, energy, transport and postal services sectors and repealing Directive 2004/17/EC, hereinafter the Utilities Directive.

3 Directive 2014/23/EU of the European Parliament and of the Council of 26 February 2014 on the award of concession contracts, hereinafter the Concessions Directive.

4 Defined as the 'acquisition by means of a public contract of works, supplies or services by one or more contracting authorities from economic operators chosen by those contracting authorities, whether or not the works, supplies or services are intended for a public purpose' (Article 1(2) of the Classic Directive) or 'the acquisition by means of a supply, works or service contract of works, supplies or services by one or more contracting entities from economic operators chosen by those contracting entities, provided that the works, supplies or services are intended for the pursuit of one of the activities referred to in Articles 8 to 14' (Article 1(2) of the Utilities Directive). Interestingly, although 
contracts (whether for works, supplies or services) and concessions are 'contracts for pecuniary interest concluded in writing' (emphasis added). ${ }^{5}$

In European Union law, the term 'contract' may be interpreted narrowly (contract sensu stricto, i.e. within the meaning of the Utilities Directive only) or broadly (contract sensu largo). 'Contracts sensu largo' cover, firstly, those regulated by the public procurement directives, i.e. public contracts, contracts sensu stricto and concession contracts; secondly, contracts awarded on the basis of acts of secondary law other than the public procurement directives, e.g. Directive 2009/81/EC6 or Regulation (EC) 1370/20077 and, thirdly, contracts awarded based on general principles of European Union law, in the awarding of which, public procurement directives (or other acts of secondary law) do not apply or apply only partially, but which fall under the scope of EU law.

One may argue, however, that the notion of a 'contract' does not fill the entire scope of EU public procurement law since, apart from (public) contracts and concessions, a public-private partnership (hereinafter the PPP) 'phenomenon'8 also exists. According to former Advocate General D. Ruiz-Jarabo Colomer, the absence of EU harmonisation 'precludes the

the Concessions Directive refers to the notion of 'procurement', it does not define it, contrary to the Classic Directive or the Utilities Directive.

5 See Article 5(1) of the Concessions Directive, Article 2(1)(5) of the Classic Directive and Article 2(1) of the Utilities Directive.

6 Directive 2009/81/EC on the coordination of procedures for the award of certain works contracts, supply contracts and service contracts by contracting authorities or entities in the fields of defence and security, and amending Directives 2004/17/EC and 2004/18/EC.

7 Regulation (EC) 1370/2007 of the European Parliament and of the Council of 23 October 2007 on public passenger transport services by rail and by road and repealing Council Regulations (EEC) Nos 1191/69 and 1107/70. Pursuant to Article 5(1) of Regulation 1370/2007, "public service contracts shall be awarded in accordance with the rules laid down in this Regulation. However, service contracts or public service contracts as defined in Directives 2004/17/EC or 2004/18/EC [currently 2014/25/EU or 2014/24/EU, respectively] for public passenger transport services by bus or tram shall be awarded in accordance with the procedures provided for under those Directives where such contracts do not take the form of service concessions contracts as defined in those Directives. Where contracts are to be awarded in accordance with Directives 2004/17/EC or 2004/18/EC, the provisions of paragraphs 2 to 6 of this Article shall not apply'. This means that service concessions (irrespective of the type of transport) and public service contracts for public passenger transport services by metro and railway are regulated only by the provisions of Regulation 1370/2007.

8 As it was called by the Green Paper on public-private partnerships and Community law on public contracts and concessions. COM/2004/0327 final. 
emancipation of PPPs as true contracts, but that does not preclude recognition of the fact that these neophyte instruments of cooperation include certain clauses which are contractual in nature or which resemble the characteristics of a concession' ${ }^{\prime}$ (emphasis added). Indeed, there are authors who consider concessions as one of major legal types of PPPs. ${ }^{10}$ Others even called them 'user-pay PPPs', in order to emphasise that the return on investment of the private operator is derived from service operation and, more generally, from users' payments. ${ }^{11}$

Although there is a link between PPPs and concessions, for some reasons only the latter have been harmonised at the European Union level. The purpose of this introductory chapter is not to discuss the content of EU regulation in the field of concessions or PPPs but rather to look at how the European Union decided to regulate concessions and PPPs within the realm of European Union law and consider the reasons behind such choice.

\section{REGULATION ON CONCESSIONS IN EU LAW}

From the point of view of the scope of application of EU public procurement law, the adoption of the Concessions Directive is deemed to be the most significant innovation. ${ }^{12}$ This is because, to date, the award of concession contracts was subject to a limited number of secondary law provisions. The limited rules governing public works concessions were stipulated only in Directive 2004/18/EC of the European Parliament and of the Council of 31 March 2004 on the coordination of procedures for the award of public works contracts, public supply contracts and public service contracts. ${ }^{13}$ Directive 2004/17/EC of the European Parliament and of the Council of 31 March 2004 coordinating the procurement procedures of entities operating in the water, energy, transport and postal

\footnotetext{
9 See opinion in Case C-196/08, Acoset, ECLI:EU:C:2009:332, para. 57.

10 See Christopher Bovis, The Law of EU Public Procurement (Oxford University Press 2015) 592.

11 Julie de Brux and Stéphane Saussier, 'Introduction: The Economics of Public-Private Partnership' in Stéphane Saussier and Julie de Brux (eds), The Economics of Public-Private Partnerships: Theoretical and Empirical Developments (Springer 2018) 4.

12 R. Caranta, 'The Changes to the Public Contract Directives and the Story They Tell about how EU Law Works' (2015) 52 CMLR 405, 429.

13 OJ L 134, pp. 114-240.
} 
services ${ }^{14}$ sectors excluded both works concessions and service concessions from the scope of its application.

The road to the Concessions Directive was long and winding. The term 'concession' first appeared in the secondary legislation as early as 1971. ${ }^{15}$ However, as aptly noted by Francisco L. Hernández González, the sole purpose of inserting the notion of 'concession' into the text of the Council Directive was to establish its exclusion from the rules governing public works contracts. ${ }^{16}$ 'Public works concession' was defined at the time as a contract of the same type as a public works contract except for the fact that the consideration for the works to be carried out consists either solely in the right to exploit the construction or in this right together with payment. ${ }^{17}$ This definition was reiterated in Council Directive 93/37/EEC of 14 June 1993 concerning the coordination of procedures for the award of public works contracts. ${ }^{18}$ In the meantime, in 1991, the Commission made a first, unsuccessful attempt at creating a legal framework for 'public service concessions'.${ }^{19}$

Notably, the first directives regulating concessions at EU level focused on the origin of the consideration received by the concessionaire. This was changed by the Court of Justice of the European Union (hereinafter the Court) in 2008 - the traditional criterion gave place to a new idea, i.e. the transfer of operating risk to the contractor. ${ }^{20}$ Based on case law of the

14 OJ L 134, pp. 1-113.

15 See Article 3(1) of Council Directive 71/305/EEC of 26 July 1971 concerning the coordination of procedures for the award of public works contracts. OJ L 185, pp. 5-14.

16 F.L. Hernández González, 'The Evolving Concept of Works and Service Concessions in European Union Law' (2016) 25 PPLR 51, 52.

17 See Article 1 of Council Directive 89/440/EEC of 18 July 1989 amending Directive 71/305/EEC concerning coordination of procedures for the award of public works contracts. OJ L 210, pp. 1-21.

18 OJ L 199, pp. 54-83.

19 F.L. Hernández González, 'The Evolving Concept of Works and Service Concessions in European Union Law' (2016) 25 PPLR 51, 52. Eventually, 'service concession' was defined by the aforementioned Directive 2004/18/EC. See Article 1(4) thereof which defined service concession as 'a contract of the same type as a public service contract except for the fact that the consideration for the provision of services consists either solely in the right to exploit the service or in this right together with payment'.

20 Case C-437/07 Commission of the European Communities v Italian Republic, ECLI:EU:C:2008:624. This slightly forgotten case is highlighted by F.L. Hernández González in 'The Evolving Concept of Works and Service Concessions in European Union Law' (2016) 25 PPLR 51, 54. The concept of 'operating risk' was further developed in the case law, suffice to mention Case 
Court, the Concessions Directive provided new definitions of 'concession contracts'. ${ }^{21}$ They now mean contracts for pecuniary interest concluded in writing by means of which one or more contracting authorities or contracting entities entrust the execution of works ('works concession') or provision and the management of services other than the aforementioned execution of works ('services concession') to one or more economic operators, the consideration for which consists either solely in the right to exploit the works that are the subject of the contract or in that right together with payment. ${ }^{22}$

The Concessions Directive was adopted mainly because of a risk of legal uncertainty related to divergent interpretations of EU law by national legislators and wide disparities among the legislations of various Member States. ${ }^{23}$ However, the adoption of the Concessions Directive, as a standalone instrument, has already been criticised in the literature. Sue Arrowsmith pointed out that while the basic purpose of the Concessions

C-206/08, Eurawasser, ECLI:EU:C:2009:540 and Case C-274/09, Privater Rettungsdienst und Krankentransport Stadler, ECLI:EU:C:2011:130. Nonetheless, the said F.L. Hernández González is of the opinion that the distinction between a concession contract and a public contract now requires a full and detailed economic analysis of each contract, the purpose of which is to verify the transfer of operating risk, which will make legal classification of contracts even more complex. Ibid., at 55. Similarly, Albert Sanchez Graells noted that the criteria for the classification of a given contract as a concession or a 'regular' works or service contract are neither watertight nor perfectly objective. See A. Sanchez Graells, 'What Need and Logic for a New Directive on Concessions, Particularly Regarding the Issue of Their Economic Balance' (2012) 2 EPPPL 94, 96.

21 See also Recital 18 of the Concessions Directive: 'Difficulties related to the interpretation of the concepts of concession and public contract have generated continued legal uncertainty among stakeholders and have given rise to numerous judgments of the Court of Justice of the European Union. Therefore, the definition of concession should be clarified, in particular by referring to the concept of operating risk. The main feature of a concession, the right to exploit the works or services, always implies the transfer to the concessionaire of an operating risk of economic nature involving the possibility that it will not recoup the investments made and the costs incurred in operating the works or services awarded under normal operating conditions even if a part of the risk remains with the contracting authority or contracting entity.'

22 See Article 5(1).

23 See Recital 4. In this context, see also the first ever soft law devoted to concessions: the Commission interpretative communication on concessions under Community law (OJ 2000 C 121, p. 2). This Communication acknowledged that concession contracts are not defined in the Treaty and that the secondary legislation is strained. The Commission emphasised that this does not mean that concessions are not subject to the rules and principles set out in the Treaty. 
Directive was to reduce uncertainty, the decision to have a separate legislation in place rather than apply more familiar general rules to concessions limits the extent to which certainty of procedures has been achieved. ${ }^{24}$ Francisco L. Hernández González held that the arrival of the Concessions Directive on the scene brought no radical changes. ${ }^{25}$ In the view of Albert Sanchez Graells, the separation of instruments is prone to generating legal uncertainty and litigation, and may be regarded as far from optimal regulatory strategy. ${ }^{26}$

On the other hand, Roberto Caranta indicated that concession contracts have generally specific characteristics such as high value, long duration and the related necessity for adjustments to be made from time to time to the relevant contract terms, "which certainly make it necessary to have some rules which are somewhat different from those applicable to procurement contracts'. ${ }^{27}$ Also, Richard Craven, setting aside any debate over the need for a separate directive specifically addressing concessions and procurement, noted that the Concessions Directive 'enhances legal certainty by confirming the approach of the Court of Justice and fleshing out detail in certain areas (selection and award criteria)' ${ }^{28}$

Getting back to the Concessions Directive itself, with 88 recitals, 55 Articles and 11 annexes, the text of the Concessions Directive is the shortest amongst the public procurement directives enacted in 2014. It adopts a similar format thereto which means that it is divided into five Titles: (I) Subject matter, scope, principles and definitions (Articles 1-29); (II) Rules on the award of concessions: general principles and procedural guarantees (Articles 30-41); (III) Rules on performance of

24 Sue Arrowsmith, The Law of Public and Utilities Procurement: Regulation in the EU and UK, Volume 2 (Sweet \& Maxwell 2018) 5.

25 F.L. Hernández González, 'The Evolving Concept of Works and Service Concessions in European Union Law' (2016) 25 PPLR 51, 59.

26 A. Sanchez Graells, 'What Need and Logic for a New Directive on Concessions, Particularly Regarding the Issue of Their Economic Balance' (2012) 2 EPPPL 94, 97.

27 R. Caranta, 'The Changes to the Public Contract Directives and the Story They Tell about how EU Law Works' (2015) 52 CMLR 391, 429.

28 R. Craven, 'The EU's 2014 Concessions Directive' (2014) 23(4) PPLR 188,197 . In the same manner, Martin Farley and Nicolas Pourbaix who point out that the introduction of the Concessions Directive and the increased legal certainty it brings to areas such as the definition is a welcome development. See M. Farley and N. Pourbaix, 'The EU Concessions Directive: Building (Toll) Bridges between Competition Law and Public Procurement?' (2015) 6(1) Journal of European Competition Law \& Practice 15, 25. 
concessions (Articles 42-45); (IV) Amendments of Directives 89/665/ EEC and 92/13/EEC (Articles 46-47);29 and (V) Delegated powers, implementing powers and final provisions (Articles 48-55). As mentioned in the Introduction, this chapter does not pertain to the content of the Concessions Directive. Having said that, two things need to be emphasised.

First of all, as aptly pointed out by Sue Arrowsmith, there is actually little difference in the applicable procedures between the Concessions Directive and the other public procurement directives, the structure of the award procedure, the possibility for using bidder-related criteria and the scope for post-contract modifications. ${ }^{30}$ In her view, it is far from clear that the other directives do not provide for adequate rules for awarding concessions. ${ }^{31}$ Provisions concerning grounds for exclusion contained in the Concessions Directive can be a good example as they essentially mirror the provisions of the Classic Directive. Such similarities do not help in eliminating doubts about the need for a separate regime for concessions at all.

Secondly, pursuant to Article 8 of the Concessions Directive, the directive applies to concession contracts the value of which is equal to or greater than EUR 5350 000.32 As stated in Recital 23, this threshold should reflect the clear cross-border interest in concessions to economic operators located in Member States other than that of the contracting authority or the contracting entity. In other words, the intention of Article 8 was apparently to provide a clear-cut distinction pursuant to which below-threshold concession contracts are not subject to the regime stipulated in the Concessions Directive. It seems, however, that by using the adjective 'clear', the Concessions Directive, nomen omen, clearly submits that if the value of a concession contract is lower than the stipulated threshold, then it automatically means that a cross-border

29 Thanks to these amendments, the Remedies Directives are fully applicable to works and services concessions, as regulated by the Concessions Directive.

30 Sue Arrowsmith, The Law of Public and Utilities Procurement: Regulation in the EU and UK, Volume 2 (Sweet \& Maxwell 2018) 5.

31 Sue Arrowsmith, 'Revisiting the Case against a Separate Concessions Regime in the Light of the Concessions Directive: A Specific Directive without Specificities?' in Fabian Amtenbrink, Gareth Davies, Dimitry Kochenov and Justin Lindeboom (eds), The Internal Market and the Future of European Integration: Essays in Honour of Laurence W. Gormley (Cambridge University Press 2019) 382.

32 As envisaged by Commission Delegated Regulation (EU) 2019/1827 of 30 October 2019 amending Directive 2014/23/EU of the European Parliament and of the Council in respect of the threshold for concessions. OJ L 279, p. 23. 
interest does not exist. Simply, in such case the cross-border interest has to be determined, since it is not 'clear' at the outset that it exists. If it is determined, then the general principles of EU public procurement law should apply. ${ }^{33}$ The above means that the Concessions Directive missed the chance to introduce a strict threshold (based on value or otherwise) that would allow Member States to rely on bright-line tests in determining the need to comply (or not) with the obligations derived from general principles. ${ }^{34}$

To sum up, although the Concessions Directive sought to provide greater certainty, it seems that, to quote AG Nils Wahl, ${ }^{35}$ the contours of EU public procurement law following the adoption of the Concessions Directive will probably remain unclear.

\section{REGULATION ON PUBLIC-PRIVATE PARTNERSHIPS IN EU LAW}

Contrary to concessions, European Union law does not contain separate regulations concerning PPPs, at the level of either primary or secondary law. It is submitted that the absence of such regulations stems from the lack of the general competence of the European Union to issue acts concerning PPPs and the wording of Article 5(3) TEU, namely the principle of subsidiarity. ${ }^{36}$ However, it should be recalled that in 2000 the European Parliament invited the Commission to examine the possibility of adopting a draft Directive aimed at introducing 'homogeneous rules for the sector of concessions and other forms of PPPs' ${ }^{37}$ The Economic and Social Committee also considered that such a legislative initiative

33 See P. Bogdanowicz, 'Cross-border Interest and Concession Contracts: A Critical Approach' (2015) 10(2) EPPPL 83, 89.

34 A. Sanchez Graells, 'The Continuing Relevance of the General Principles of EU Public Procurement Law after the Adoption of the 2014 Concession Directive' (2015) 12 University of Leicester School of Law Research Paper 1, 5. 35 See opinion of AG N. Wahl in Case C-207/13 Wagenborg Passagiersdiensten $B V$ ECLI:EU:C:2014:590, para. 105.

36 See M.J. Werner, 'European Union', in M. Button (ed.), A Practical Guide to PPP in Europe (City \& Financial Publishing 2008) 13.

37 Opinion of the European Parliament (first reading) on the proposal of the Commission, COM (2000) 275, 10.05.2002. It was not the only activity of the European Parliament in this regard. See also the Parliament's resolution on public-private partnerships and Community law on public procurement and concessions (2006/2043(INI)). 
was called for. ${ }^{38}$ As we know, no real results emerged from that, at least as far as PPPs are concerned.

It was as late as 2013 that the term 'public-private partnership' was introduced to EU secondary law, through the provisions of Regulation (EU) 1303/2013. ${ }^{39}$ This Regulation lays down the common rules applicable to the European Structural and Investment (ESI) funds. EU institutions saw that PPPs can be an effective means of delivering operations which ensure the achievement of public policy objectives by bringing public and private resources together in different forms. ${ }^{40}$ Regulation (EU) 1303/2013 defined PPP as a form of cooperation between public bodies and the private sector, aimed at improving the delivery of investments in infrastructure projects or other types of operations, delivering public services through risk sharing, the pooling of private sector expertise or additional sources of capital. ${ }^{41}$ This is the first definition of PPP in such an important act of the Union's secondary law. Notably, a separate chapter of the Regulation has been devoted to support offered to PPP operations through the ESI funds (Articles 62-64). It also confirms the role of the European Investment Bank in promoting PPPs by pointing out that the Bank may, at the request of Member States, participate in activities relating to the preparation of operations, in particular major projects, financial instruments and PPPs. ${ }^{42}$

The lack of specific provisions of European Union law directly regulating issues related to PPP did not impede the actions of European institutions, including but not limited to the Commission, which has actively promoted PPP in the EU for several years. In this context, two soft law instruments deserve particular attention: the Commission's 'Green Paper on public-private partnerships and Community law on

38 Opinion, ESC, OJ C 14, 16.1.2001, rapporteur Mr Levaux, point 4.1.3 and Opinion, ESC, OJ C 193, point 3.5.

39 Regulation (EU) 1303/2013 of the European Parliament and of the Council of 17 December 2013 laying down common provisions on the European Regional Development Fund, the European Social Fund, the Cohesion Fund, the European Agricultural Fund for Rural Development and the European Maritime and Fisheries Fund and laying down general provisions on the European Regional Development Fund, the European Social Fund, the Cohesion Fund and the European Maritime and Fisheries Fund and repealing Council Regulation (EC) No 1083/2006 merits particular attention (OJ EU UE L No. 347, p. 320).

$40 \quad$ See Recital 59.

41 See Article 2(24).

42 See Article 31. Examples of PPPs supported by the European Investment Bank may be found here: https://www.eib.org/attachments/epec/epec_ppps_ financed_by_eib_since_1990_en.pdf 
public contracts and concessions' (Green Paper) published in 2004 and 'Commission interpretative communication on the application of Community law on Public Procurement and Concessions to institutionalised PPP (IPPP)'43 (Communication) issued in 2008.

In the Green Paper, the Commission defined PPPs as "forms of cooperation between public authorities and the world of business which aim to ensure the funding, construction, renovation, management or maintenance of an infrastructure or the provision of a service'. ${ }^{44}$ The Commission pointed to four factors that normally characterise PPPs: first, the relatively long duration of the relationship, involving cooperation between the public partner and the private partner on different aspects of a planned project; second, the method of funding the project, in part from the private sector, sometimes by means of complex arrangements between the various players; ${ }^{45}$ third, the important role of the economic operator who participates at different stages of the project (design, completion, implementation, funding), ${ }^{46}$ in comparison to the public partner which concentrates primarily on defining the objectives to be attained in terms of public interest, the quality of services provided and the pricing policy, and takes responsibility for monitoring compliance with these objectives; and fourth, the distribution of risks between the public partner and the private partner to which the risks generally borne by the public sector are transferred. ${ }^{47}$

The Commission noted that EU law does not lay down any special rules to cover the 'phenomenon of PPPs'. However, the Commission

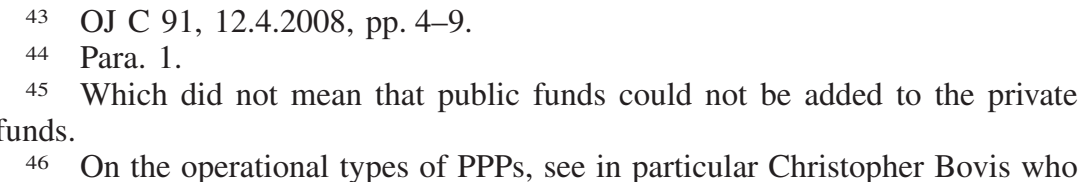
shows that at least ten formats of PPPs exist: Design-build-finance-operate (DBFO); Build-own-operate (BOO); Build-develop-operate (BDO); Designconstruct-manage-finance (DCMF); Buy-build-operate (BBO); Lease-developoperate (LDO); Operate-under-licence (OL); Build-operate-transfer (BOT); Build-own-operate-transfer (BOOT); and Build-lease-operate-transfer (BLOT). Christopher Bovis, The Law of EU Public Procurement (Oxford University Press 2015) 607.

47 The Commission emphasised, however, that a PPP does not necessarily mean that the private partner assumes all the risks or even the major share of the risks linked to the project. As the Commission continued in para. 2 of the Green Paper, the precise distribution of risk 'is determined case by case, according to the respective ability of the parties concerned to assess, control and cope with this risk'. 
emphasised that any act, whether contractual or unilateral, whereby a public entity entrusts the provision of an economic activity to a third party, must be examined in light of the rules and principles resulting from the Treaty on the functioning of the European Union (at the time, the Treaty establishing the European Community), particularly as regards the principles of the freedom of establishment and the freedom to provide services which encompass in particular the principles of transparency, equal treatment, proportionality and mutual recognition. This once again confirms the extent to which PPPs are connected with EU public procurement law; suffice to mention that the wording of Recital 1 of the Classic Directive is nearly identical.

At the same time, the Commission admitted that there are views according to which the existing EU rules 'are insufficiently clear and lack homogeneity between the different Member States', ${ }^{48}$ and recalled the aforementioned positions of different institutions as to adoption of a uniform act on PPPs. Consequently, the main aim of the Green Paper was to show the extent to which Community rules apply to selection of the private partner and to the subsequent phase, with a view to identifying any uncertainties, and to analysing the extent to which the Community framework is suited to the imperatives and specific characteristics of PPPs. ${ }^{49}$

As part of the analysis, the Commission proposed making a distinction between 'PPPs of a purely contractual nature', in which the partnership between the public and the private sector is based solely on contractual links, and 'PPPs of an institutional nature', involving cooperation between the public and the private sector within a distinct entity. 'Purely contractual PPPs' cover a variety of set-ups (models) within which one or more tasks of varying magnitude are assigned to the private partner, including potentially the design, funding, execution, renovation or exploitation of a work or service. This includes, among other things, the concessive model the set-up PFI. ${ }^{50}$ Within this model, the remuneration for the private partner does not take the form of charges paid by the users of the works or of the service, but instead regular payments made by the public partner. These payments may be fixed, but may also be calculated, for example, on the basis of the availability of the works or the related services, or even based on the level of use of the works.

\footnotetext{
48 Para. 14.

49 Para. 18.

50 The term PFI refers to 'Private Finance Initiative', a programme of the British Government developed in the 1990s and permitting the modernisation of public infrastructure through recourse to private funding.
} 
In the Green Paper, the Commission noted that competitive dialogue, as regulated by public procurement directives, might be of particular relevance to the PPPs. In the view of the Commission, the competitive dialogue procedure should provide the necessary flexibility in the discussions with the candidates on all aspects of the contract during the set-up phase, while ensuring that these discussions are conducted in compliance with the principles of transparency and equal treatment, and do not endanger the rights conferred by the Treaty on economic operators. ${ }^{51}$

As regards the phase following selection of the private partner, the Commission recalled that it is primarily governed by contractual provisions stemming from national laws. In this context, one has to remember that the Green Paper was published in 2004, i.e. long before public procurement directives introduced the instrument of modification (change) of contract to the secondary law of the European Union. However, the Commission aptly noted that PPPs concern a service spread out in time and must therefore be able to evolve in line with changes in the macro-economic or technological environment, and in line with general interest requirements.52 Consequently, the Commission pointed out that the descriptive documents sent to the tenderers or candidates during the selection procedure may provide for automatic adjustment clauses, such as price-indexing, or stipulate the circumstances under which the rates charged may be revised. They can also stipulate review, on condition that the respective clauses identify precisely the circumstances and conditions under which adjustments to the contractual relationship can be made. ${ }^{53}$ In the view of the Commission, unregulated modifications can be acceptable only if forced by an unforeseen circumstance or justified on grounds of public interest. Additional works or services may also be considered, however, the interpretation thereof must be restrictive. It is not difficult to see that situations in which a PPP

51 Para. 26.

52 Para. 47. In this context see S. Van Garsse, E. Van Den Broek and J. Buyck, 'PPP Contracts: Amendments to PPP Projects Based on Experience in Flanders' (2016) 11(2) EPPPL 111.

53 See, however, Marta Andrecka who aptly notes that in long lasting contracts such as PPP ones it is very difficult to predict and include all clauses relevant for the establishment and future operation of the PPP in the initial contract. Marta Andrecka, Public-Private Partnership in the EU Public Procurement Regime (GlobeEdit 2014) 276. 
contract may be modified resemble admissible modifications under current public procurement directives. ${ }^{54}$

Furthermore, the Commission required that the period during which the private partner will undertake the performance of a work or a service must be fixed with a view to guaranteeing the economic and financial stability of a project. In particular, the duration of relationship between the partners must be set so that it does not limit open competition beyond what is required to ensure that the investment is paid back and a reasonable return on invested capital is achieved. An excessive duration is likely to be censured on the basis of the principles governing the internal market or the provisions of the Treaty governing competition. ${ }^{55}$ In fact, this was reflected later on by the Concessions Directive. ${ }^{56}$

As regards IPPP, the interpretative communication on the application of Community law on Public Procurement and Concessions to institutionalised PPP (IPPP), issued after the Green Paper and in response to the European Parliament's resolution from 2006,57 sheds light on the Commission's understanding of how the Community provisions on public procurement and concessions are to be applied to the founding and operation of IPPP. ${ }^{58}$

The Commission noted that, in practice, an IPPP is usually set up either by founding a new company with the capital held jointly by the contracting entity and the private partner or, in certain cases, by several contracting entities and/or several private partners, and through awarding a public contract or a concession to this newly founded public-private entity, or by the participation of a private partner in an existing publicly

54 On the modifications of PPP in practice, see in particular Jean Beuve, Aude le Lannier and Zoé Le Squeren, 'Renegotiating PPP Contracts: Opportunities and Pitfalls' in Stéphane Saussier and Julie de Brux (eds), The Economics of Public-Private Partnerships: Theoretical and Empirical Developments (Springer 2018) 135-162.

55 Para. 46.

56 See Article 18, which provides that the duration of concessions shall be limited and holds that for concessions lasting more than five years, the maximum duration of the concession shall not exceed the time that a concessionaire could reasonably be expected to take to recoup the investments made in operating the works or services together with a return on invested capital taking into account the investments required to achieve the specific contractual objectives.

57 The European Parliament's resolution on public-private partnerships and Community law on public procurement and concessions (2006/2043(INI)).

58 Green Paper also contained some considerations on the IPPP. 
owned company which has obtained public contracts or concessions by itself in the past. 59

The Commission emphasised that irrespective of how the IPPP is set up, EU law requires a contracting entity to follow a fair and transparent procedure, either when selecting the private partner which supplies goods, works or services through its participation in the IPPP or when granting a public contract or a concession to the public-private entity. ${ }^{60}$ However, the Commission did not consider a double tendering procedure as practical, either in selecting the private partner to the IPPP or in awarding public contracts or concessions to the public-private entity. ${ }^{61}$ Consequently, the Commission proposed a way of setting up an IPPP which it deems potentially compliant with the principles of EU law while at the same time allowing a double tendering procedure to be avoided. Pursuant to it, the private partner of the IPPP is selected under a procedure, the subject of which is both the public contract or the concession to be awarded to the future public-private entity and the private partner's operational contribution to performance of the tasks at hand and/or to the management of the public-private entity. The selection of the private partner is accompanied by the founding of the IPPP and the awarding of the contract or concession to the public-private entity.

To sum up, the actions of the Commission in the field of PPPs should be read primarily as assistance on the part of the EU in the process of promotion and implementation of PPP as a form of performing public tasks. It is submitted, however, that the Commission expresses its role with caution. ${ }^{62}$ It seems that more determined steps on the part of the

59 Point 2.2.

60 This was also clearly stated by the Court of Justice in Case C-196/08 Acoset, ECLI:EU:C:2009:628, para. 57.

61 It is generally accepted in literature. See e.g. Sue Arrowsmith, The Law of Public and Utilities Procurement: Regulation in the EU and UK, Volume 2 (Sweet \& Maxwell 2018) 360 and Marta Andrecka, 'Institutionalised PublicPrivate Partnership as a Mixed Contract under the Regime of the new Directive 2014/24/EU' (2014) 9(3) European Procurement \& Public Private Partnership Law Review 174, 177. See also opinion of Advocate General Ruiz-Jarabo Colomer in Case C-196/08 Acoset, ECLI:EU:C:2009:332, para. 57. See however M. Andrecka and M. Kania, 'Choosing the Private Partner for a Public Private Partnership: A European Union Law Perspective on Polish Practice' (2013) 2(1) Polish Review of International and European Law 141, 148. The authors demonstrate that the situation is not devoid of difficulties.

62 Herwig C. H. Hofmann, Gerard C. Rowe and Alexander H. Türk, Administrative Law and Policy of the European Union (Oxford University Press 2011) 553. 
Union's institutions, including but not limited to the Commission, with regard to the comprehensive harmonisation of the rules regarding PPPs cannot be expected in the nearest future. In the 'Green Paper on the modernisation of EU public procurement policy. Towards a more efficient European Procurement Market' from 2011,63 the Commission did not consider whether it should envisage proposing legislative action designed to coordinate the procedures for the award of PPPs but, instead, enquired whether 'the procedures and tools provided by the existing directives to address specific needs and to facilitate private participation in public investment through public-private partnerships (e.g. dynamic purchasing system, competitive dialogue, electronic auctions, design contests) should be maintained in their current form, modified (if so, how) or abolished?' 64 In other words, it focused its analysis on the impact of the new rules on the PPPs only. ${ }^{65}$

\section{CONCLUSIONS}

In the Green Paper, the Commission noted that a wide variety of instruments are available to make PPPs more open to competition in a transparent legal environment, i.e. legislative instruments, interpretative communications, actions to improve the coordination of national practice or the exchange of good practice between Member States. ${ }^{66}$ After more than 15 years we know that, contrary to concessions being one of the major legal types of PPPs, no legislative instruments concerning PPPs were adopted. What were the reasons behind such a choice by the EU legislator? It seems that we may find the answer in yet another soft law instrument, i.e. the Commission interpretative communication on concessions under Community law of 2000, issued long before the adoption of the Concessions Directive. In this Communication the Commission was confident that its publication would help to clarify the rules of the game

$63 \mathrm{COM} / 2011 / 0015$ final.

64 Point 2.1.

65 See in this respect e.g. M. Burnett, 'The New Rules for Competitive Dialogue and the Competitive Procedure with Negotiation in Directive 2014/24 What Might They Mean for PPP' (2015) 10(2) EPPPL 62, 63-64 and Christina D. Tvarn $\varnothing$, 'Why the EU Public Procurement Law Should Contain Rules that Allow Negotiation for Public Private Partnership' in Grith Skovgaard Ølykke, Carina Risvig Hansen and Christina D. Tvarnø (eds), EU Public Procurement Modernisation, Growth and Innovation. Discussions on the 2011 Proposals for Procurement Directives (DJØF Publishing 2012) 201-219.

66 Para. 18. 
and open up markets to competition in the field of concessions. At the same time, the Commission held that the publication of the Communication 'in no way prejudices possible future proposals for legislation on concessions, if this becomes necessary to reinforce legal certainty'. ${ }^{67}$ Indeed, ten years later it proposed adopting the Concessions Directive with a view to providing greater certainty.

Setting aside any debate on whether the Commission achieved its aim, or not, one may argue that as long as the Commission does not consider a legislative instrument concerning PPPs as providing legal greater certainty, there will be no legislative intervention on the Commission's part. Consequently, PPPs will be carried out on a basis of either national laws implementing the Classic Directive or the Utilities Directive, or the provisions implementing the Concessions Directive.

67 Point 3.3. 